\title{
A Practical Drug Discovery Project at the Undergraduate Level
}

M. Jonathan Fray, ${ }^{, \mathrm{a}}$ Ian R. Baldwin, ${ }^{\mathrm{b}}$ Nick Barton, ${ }^{\mathrm{b}}$ Jack Brown, ${ }^{\mathrm{b}}$ Ian B. Campbell, ${ }^{\mathrm{b}}$ Ian Churcher, ${ }^{\mathrm{b}}$ Diane M. Coe, ${ }^{b}$ Anthony W.J. Cooper, ${ }^{b}$ Andrew P. Craven, ${ }^{b}$ Gail Fisher, ${ }^{b}$ Graham G. A. Inglis, ${ }^{b}$ Henry A. Kelly, ${ }^{b}$ John Liddle, ${ }^{b}$ Simon J.F. Macdonald, ${ }^{b}$ Aoife C. Maxwell, ${ }^{b}$ Vipulkumar K. Patel, ${ }^{b}$ Stephen Swanson, ${ }^{b}$ and Natalie Wellaway ${ }^{b}$

a School of Chemistry, University of Nottingham, University Park, Nottingham, NG7 2RD, UK.

and ${ }^{\mathrm{b}}$ GlaxoSmithKline, Medicines Research Centre, Gunnels Wood Road, Stevenage, Herts., SG1 2NY, UK.

Corresponding author: jonathan.fray@nottingham.ac.uk Tel. +44 (0)115 8466887. MJF holds a University of Nottingham Teaching Fellowship funded by GSK.

\section{Teaser}

"You make the compounds you design". This article describes a new way for chemistry undergraduates to learn about drug discovery through a series of lecture-workshops, target compound design and laboratory work.

Keywords undergraduate, research, mini-project, drug design, synthesis, PI3Kס

\begin{abstract}
A practical drug discovery project for third-year undergraduates is described. No previous knowledge of medicinal chemistry is assumed. Initial lecture-workshops cover the basic principles; then students are asked to improve the profile of a weakly potent, poorly soluble PI3K $\delta$ inhibitor (1). Compound array design, molecular modelling and screening data analysis are followed by laboratory work in which each student, as part of a team, attempts to synthesise at least two target compounds. The project benefits from significant industrial support, including lectures, student mentoring and consumables. The aim is to make the learning experience as close as possible to real-life industrial situations. Forty-eight target compounds have been prepared, the best of which $(\mathbf{5 b}, \mathbf{5 j}, \mathbf{6} \mathbf{b}$ and $\mathbf{6} \mathbf{a p})$ improved the potency and aqueous solubility of the lead compound (1) by 100-1000 fold and $\geq 10$-fold, respectively.
\end{abstract}

\section{Introduction}

This paper is an account of a 'hands-on' drug discovery course that we have been running for the past three years at the University of Nottingham. The purpose is five-fold: to teach students, who are in the third year of a four-year MSci degree course, how new medicines are discovered; to give an appreciation of the role of the chemist in that process; to give students practice in compound design and data interpretation; to use industry-standard equipment and methods in the laboratory; and to develop communication, team-working and inter-personal skills. Key aspects of the course were the participation of scientists from GlaxoSmithKline (GSK) as lecturers and workshop mentors, and, above all, in the practical application of drug discovery principles in the laboratory.

From GSK's perspective, the aim and guiding principle was to train "industry ready" graduates for employment in medicinal chemistry by the pharmaceutical industry. In this context, "industry ready" meant students who have been taught applied medicinal chemistry as practised in industry as opposed to the less applied approaches usually found in academia. A substantial part of the course is taught not by professional teachers but by enthusiastic professional medicinal chemists. This provided an up to date perspective reflecting current industrial practice and science of drug discovery, rather than a case history describing science and processes from the past. 
The value of investigational or research-driven laboratory projects (of varying length and complexity) has been discussed widely. ${ }^{1-3}$ Advantages are that students feel more engaged, as projects are aligned to real-life problems, ${ }^{4}$ and there is not necessarily a 'right' answer, as in real research. Indeed, it has been shown that the type of laboratory work affects views on the nature of scientific enquiry itself. ${ }^{5}$ At the University of Nottingham, the first two years' laboratory experience teaches technique through following a set of traditional 'recipe-following' laboratory experiments. By contrast, those staying on to complete the MSci fourth year research project are 'in at the deep end', having to comprehend primary literature, design experiments, and break new ground where uncertainty and failure are everyday experiences. Consequently, we sought to bridge this gap by developing projects ${ }^{6}$ that were positioned somewhere between the 'inquiry-led' (students define the problem, design experiments and analyse the data generated) and the 'research-based' (working on a real problem with potential to advance knowledge). ${ }^{7,8}$

Another reason for embarking on this work was provided by an HEA Physical Sciences survey of chemistry graduates in $2010 .^{9}$ The students were asked in retrospect to highlight 'skills deficits', i.e. skills that the graduates wished they were proficient in, once employed. Top of the list were experiment design, team working, oral presentations and time-management. Investigational projects could give much needed experience in these areas.

Course description: Principles of medicinal chemistry, project background and target design. The course and accompanying laboratory work constitute 10 credits each (students take 120 credits annually; one credit corresponding approximately to 2 hours of lectures and an equivalent amount of private study). No understanding of medicinal chemistry is assumed. The principles are taught through five, two-hour workshops which follow a relatively conventional form - a brief description is provided below. Assessment of this part of the module is through a 90 minute written examination.

- Introduction to the process of Drug Discovery - what it takes to discover a new medicine, emphasising the role of the chemist. The discovery of salmeterol for the treatment of asthma - a case history of drug discovery.

- Discussion of physicochemical properties (particularly logP and pKa). Basic principles of pharmacokinetics and drug metabolism, including tactics for blocking metabolism. Lipid crossing. Impact of acidity/basicity/lipophilicity on absorption and pharmacokinetics; Lipinski's 'Rule of Five'.

- Structure Activity Relationships and relation of structure to physicochemical properties. Hydrogen bonding and polar surface area; size; lipophilicity and electronic effects of substituents. Outlines of pharmaceutical properties (such as drug solubility and stability). Drug structure and toxicity.

- Pharmacology: drug target and target classes. Receptor pharmacology (agonists/antagonists). Enzyme inhibitors, with kinases as an example.

- Computational chemistry. Molecular interactions - how drugs bind to targets. Molecular similarity - the basis of bio-isosterism. Conformations of molecules and how to calculate them. Structure-based drug design.

After this, the course embarks on teaching skills in drug design. One workshop is used to introduce the research-based part of the course, comprising a brief description of the target disease (asthma) and the chosen therapeutic approach (kinase inhibition). Essential background on compound array design and screening is also provided. The importance of team skills is discussed, and the way this is approached is expanded upon later in this article. The students are placed in teams of six, each with 
an experienced medicinal chemist as mentor, and are asked to design compounds that address the deficiencies of a lead compound (1)(Figure 1). Three two-hour workshops are devoted to this. The lead is a weakly potent $\left(\mathrm{plC}_{50}=5.7\right)$, lipophilic (clogP $\left.=3.9\right)$ and poorly soluble $(<12 \mu \mathrm{g} / \mathrm{mL}$, aqueous $\mathrm{pH} 7$ ) inhibitor of one of the phosphatidylinositol-3-kinases (PI3K $\delta$ ), which is implicated in the pathology of asthma and chronic obstructive pulmonary disease. ${ }^{10}$

Phosphatidylinositol-3-kinases are lipid kinases whose role is to phosphorylate the 3-position hydroxyl of phosphatidylinositides. Eight different kinases are known, of which the class IA subgroup (the $\alpha$-, $\beta$-, and $\delta$ - isoforms) generates phosphatidylinositol-3,4,5-triphosphate. Interest in PI3K inhibitors has been intense in recent years, and around 20 compounds (with varying degrees of selectivity for the various isoforms) are currently in clinical development. ${ }^{11}$ For example, PI3K $\alpha$ inhibitors are being progressed as potential anti-cancer agents. ${ }^{11}$

The students work on a research programme that is live at GSK. They do not work on the structural series being pursued by GSK (and any intellectual property which results from the module is owned by the University of Nottingham), but this allows the students to feel they are connected to an ongoing effort to discover a new medicine for treating severe asthma.

A primary focus is to progress the molecular series towards an improved drug-like profile (as opposed to results for publication) by paying close attention to physicochemical properties alongside potency. The project was specifically designed to ensure the students experienced two iterations of the "analyse-design-synthesis-test" cycle ${ }^{12}$ - pivotal learning points in medicinal chemistry - despite the inexperience of the students and the very limited time available. There are three stages. Firstly, the students devise two arrays of twenty target compounds; one consisting of amine derivatives (2) (which should help improve aqueous solubility) and the other of substituted aryl derivatives (3) (to improve potency)( Figure 1). Lists of the building blocks (or monomers) used in the target compound arrays can be found in Figures 2 and 3 .

Consideration of lipophilicity, molecular weight, and hydrogen bond donor/acceptor count (Lipinski's 'Rule of Five') ${ }^{13}$ drives the selection of amines, whereas the aryl derivatives are selected by interactive visualisation on the basis of their fit and potential interactions suggested from dockings into the enzyme binding site ${ }^{14}$ derived from the parent structure established by X-ray crystallography. ${ }^{15}$ Rotations about the pyrimidine - aryl bond are also evaluated in conjunction with a potential energy plot, to determine whether other attractive, low-energy binding modes exist. Calculated logP and molecular weight data are also considered. Figure 4 shows compound 1 docked into the ATP binding site of $\mathrm{PI} 3 \mathrm{~K} \delta$. The students find the assimilation of the wealth of data quite challenging, as they have to design their arrays in only a one-hour workshop. The presence of an experienced medicinal chemist with each group during its deliberations is important to ensure logical and not random choices are made. In the case of the amine analogues, presentation of their properties through a Spotfire ${ }^{\mathrm{TM}}$ $\operatorname{plot}^{16}$ (see Figure 5) is particularly useful for visualising the chemical space. For example, initial choices could be marked on the plot to ensure an adequate diversity of structure in the array, and, if necessary re-examined before settling on the final array. The compound arrays have already been prepared by scientists at GSK, so the screening results (inhibition potency vs. PI3K $\delta\left(\mathrm{pIC}_{50}\right),{ }^{17}$ aqueous solubility ${ }^{18}$ and measured $\log \mathrm{D}^{19}$ ) are available to the students in time for the next workshop and round of design. 
Figure 1

First round of optimisation<smiles>[R]N([R])Cc1cc2nc(-c3ccccc3)nc(N3CCOCC3)c2s1</smiles>

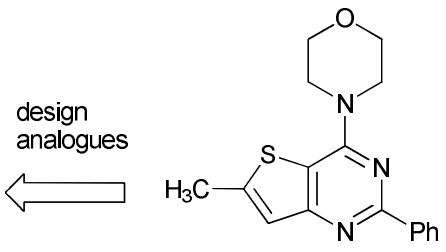

$\mathrm{plC}_{50}=5.7$

$\operatorname{clog} \mathrm{P}=3.9$

aq. sol. $<12 \mu \mathrm{g} / \mathrm{mL}$

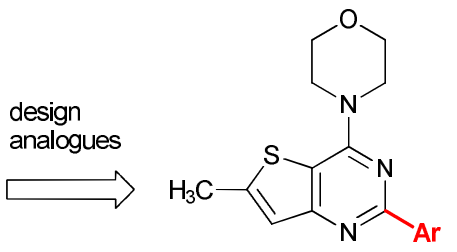

3

Second round of optimisation - phenol with various amine combinations.

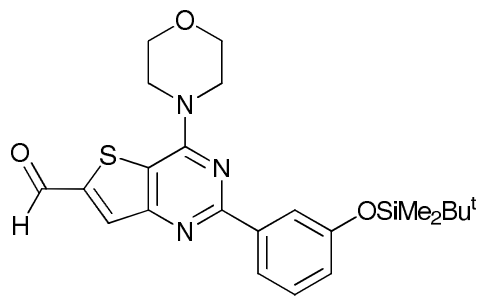

7

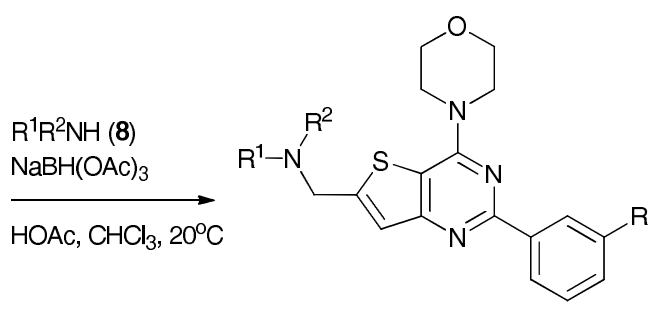

$\mathrm{NH}_{4} \mathrm{~F}$
$\mathrm{MeOH}$
$20^{\circ} \mathrm{C}$$\left(\begin{array}{l}9 \mathrm{R}=\mathrm{OSiMe}_{2} \mathrm{Bu}^{\mathrm{t}} \\ 5 \mathrm{R}=\mathrm{OH}\end{array}\right.$

Third round of optimisation - replacing the phenol with heterocyclic isosteres

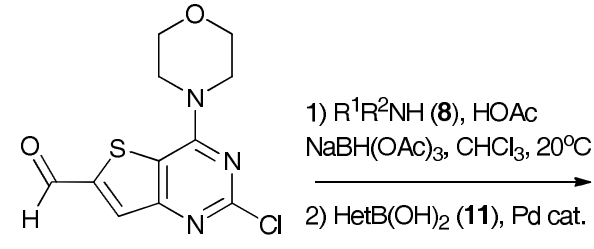

10

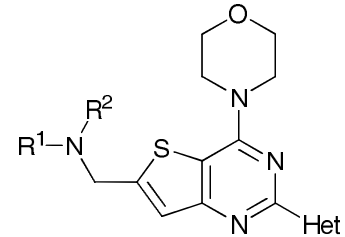

6

Palladium catalysts used in the Suzuki reaction.

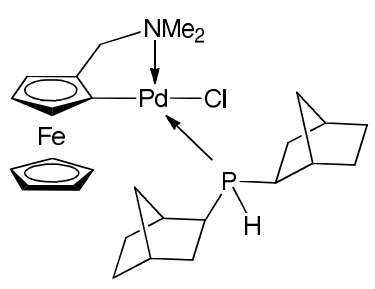

12

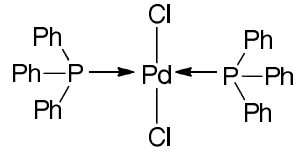

13 
Figure 2. Amine building blocks (monomers) used for the synthesis of 2 .
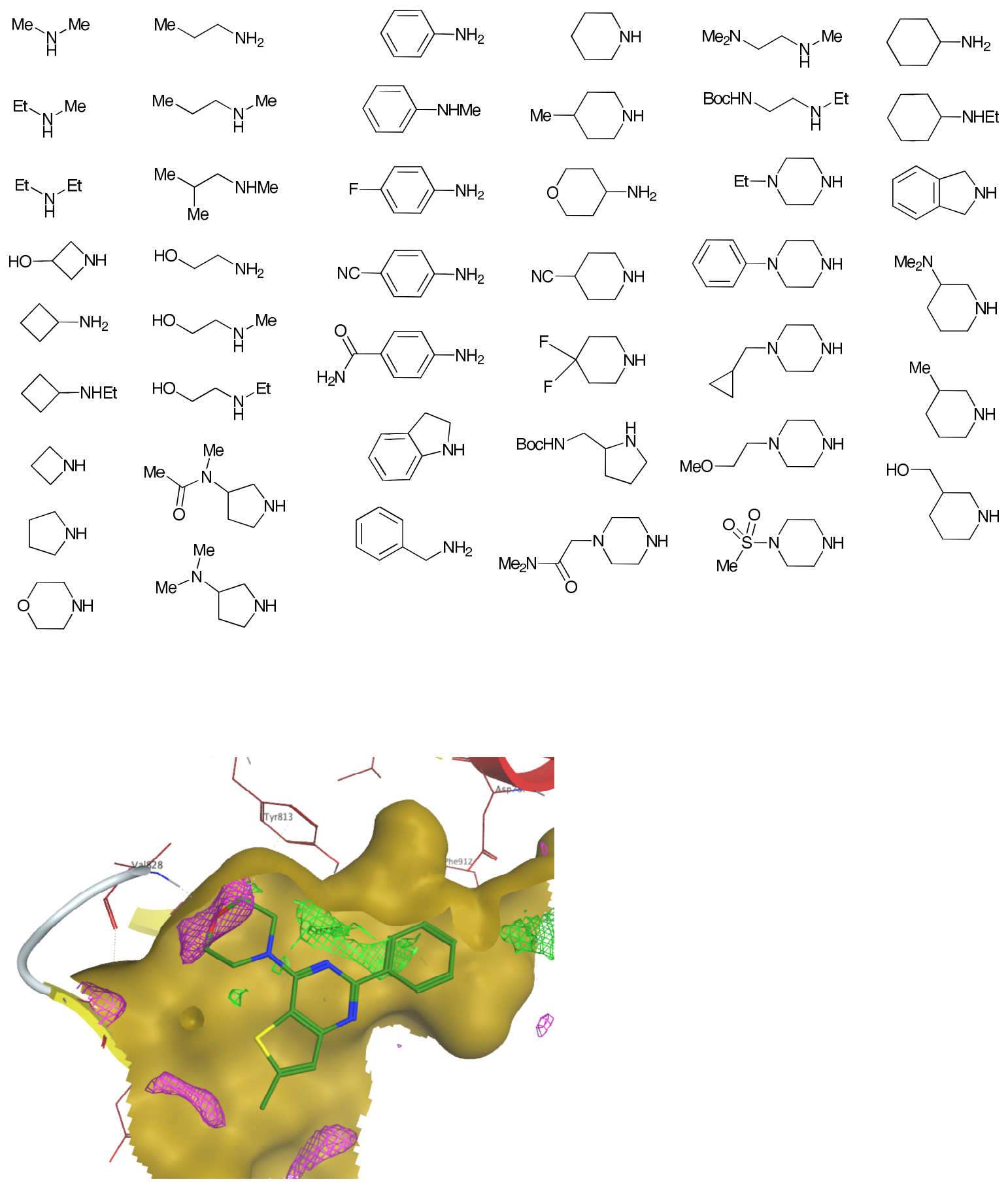

Figure 4. The reference binding mode for compound 1 was obtained from the crystal structure $2 \mathrm{WXP} .{ }^{15}$ The binding site has been surfaced and the hydrophobic (green) and polar (purple) interaction potentials were mapped by using $\mathrm{MOE}^{14}$ to help identify features of interest in the binding site and to indicate where it might be possible to make new interactions with the receptor. 
Figure 3. Building blocks (monomers), as boronic acids, used for the synthesis of 3.

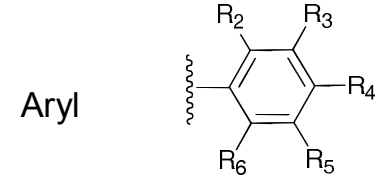

\begin{tabular}{|c|c|c|c|c|}
\hline $\mathrm{R}^{2}$ & $\mathrm{R}^{3}$ & $\mathrm{R}^{4}$ & $R^{5}$ & $\mathrm{R}^{6}$ \\
\hline $\mathrm{Me}$ & $\mathrm{H}$ & $\mathrm{H}$ & $\mathrm{H}$ & $\mathrm{H}$ \\
\hline Et & $\mathrm{H}$ & $\mathrm{H}$ & $\mathrm{H}$ & $\mathrm{H}$ \\
\hline i-Pr & $\mathrm{H}$ & $\mathrm{H}$ & $\mathrm{H}$ & $\mathrm{H}$ \\
\hline $\mathrm{CF}_{3}$ & $\mathrm{H}$ & $\mathrm{H}$ & $\mathrm{H}$ & $\mathrm{H}$ \\
\hline $\mathrm{OH}$ & $\mathrm{H}$ & $\mathrm{H}$ & $\mathrm{H}$ & $\mathrm{H}$ \\
\hline $\mathrm{OMe}$ & $\mathrm{H}$ & $\mathrm{H}$ & $\mathrm{H}$ & $\mathrm{H}$ \\
\hline $\mathrm{OPr}^{\prime}$ & $\mathrm{H}$ & $\mathrm{H}$ & $\mathrm{H}$ & $\mathrm{H}$ \\
\hline $\mathrm{CO}_{2} \mathrm{Et}$ & $\mathrm{H}$ & $\mathrm{H}$ & $\mathrm{H}$ & $\mathrm{H}$ \\
\hline $\mathrm{H}$ & $\mathrm{F}$ & $\mathrm{H}$ & $\mathrm{H}$ & $\mathrm{H}$ \\
\hline $\mathrm{H}$ & $\mathrm{Cl}$ & $\mathrm{H}$ & $\mathrm{H}$ & $\mathrm{H}$ \\
\hline $\mathrm{H}$ & $\mathrm{CF}_{3}$ & $\mathrm{H}$ & $\mathrm{H}$ & $\mathrm{H}$ \\
\hline $\mathrm{H}$ & $\mathrm{Me}$ & $\mathrm{H}$ & $\mathrm{H}$ & $\mathrm{H}$ \\
\hline $\mathrm{H}$ & i-Pr & $\mathrm{H}$ & $\mathrm{H}$ & $\mathrm{H}$ \\
\hline $\mathrm{H}$ & $\mathrm{OMe}$ & $\mathrm{H}$ & $\mathrm{H}$ & $\mathrm{H}$ \\
\hline $\mathrm{H}$ & $\mathrm{NH}_{2}$ & $\mathrm{H}$ & $\mathrm{H}$ & $\mathrm{H}$ \\
\hline $\mathrm{H}$ & $\mathrm{OH}$ & $\mathrm{H}$ & $\mathrm{H}$ & $\mathrm{H}$ \\
\hline $\mathrm{H}$ & $\mathrm{CN}$ & $\mathrm{H}$ & $\mathrm{H}$ & $\mathrm{H}$ \\
\hline $\mathrm{H}$ & $\mathrm{CO}_{2} \mathrm{H}$ & $\mathrm{H}$ & $\mathrm{H}$ & $\mathrm{H}$ \\
\hline $\mathrm{H}$ & $\mathrm{H}$ & $F$ & $\mathrm{H}$ & $\mathrm{H}$ \\
\hline $\mathrm{H}$ & $\mathrm{H}$ & $\mathrm{Me}$ & $\mathrm{H}$ & $\mathrm{H}$ \\
\hline $\mathrm{H}$ & $\mathrm{H}$ & OMe & $\mathrm{H}$ & $\mathrm{H}$ \\
\hline $\mathrm{H}$ & $\mathrm{H}$ & $\mathrm{NH}_{2}$ & $\mathrm{H}$ & $\mathrm{H}$ \\
\hline $\mathrm{H}$ & $\mathrm{H}$ & $\mathrm{CN}$ & $\mathrm{H}$ & $\mathrm{H}$ \\
\hline $\mathrm{H}$ & $\mathrm{H}$ & $\mathrm{CONH}_{2}$ & $\mathrm{H}$ & $\mathrm{H}$ \\
\hline$F$ & $\mathrm{~F}$ & $\mathrm{H}$ & $\mathrm{H}$ & $\mathrm{H}$ \\
\hline $\mathrm{F}$ & $\mathrm{H}$ & $\mathrm{F}$ & $\mathrm{H}$ & $\mathrm{H}$ \\
\hline $\mathrm{Me}$ & $\mathrm{H}$ & $\mathrm{Me}$ & $\mathrm{H}$ & $\mathrm{H}$ \\
\hline $\mathrm{F}$ & $\mathrm{H}$ & $\mathrm{Cl}$ & $\mathrm{H}$ & $\mathrm{H}$ \\
\hline $\mathrm{OMe}$ & $\mathrm{H}$ & $\mathrm{Cl}$ & $\mathrm{H}$ & $\mathrm{H}$ \\
\hline $\mathrm{F}$ & $\mathrm{H}$ & $\mathrm{H}$ & $\mathrm{Me}$ & $\mathrm{H}$ \\
\hline $\mathrm{Cl}$ & $\mathrm{H}$ & $\mathrm{H}$ & $F$ & $\mathrm{H}$ \\
\hline $\mathrm{Me}$ & $\mathrm{H}$ & $\mathrm{H}$ & $\mathrm{H}$ & $\mathrm{Me}$ \\
\hline $\mathrm{H}$ & $\mathrm{F}$ & $\mathrm{Me}$ & $\mathrm{H}$ & $\mathrm{H}$ \\
\hline $\mathrm{H}$ & $\mathrm{Me}$ & $\mathrm{Me}$ & $\mathrm{H}$ & $\mathrm{H}$ \\
\hline $\mathrm{H}$ & $\mathrm{OMe}$ & $\mathrm{OMe}$ & $\mathrm{H}$ & $\mathrm{H}$ \\
\hline
\end{tabular}

\section{Heteroaryl}
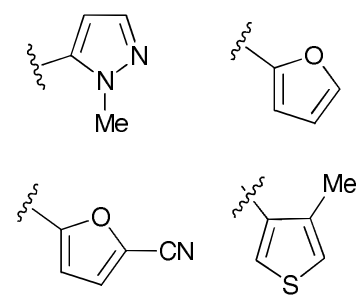

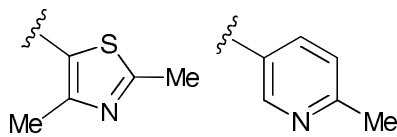<smiles>Cc1cc(C(C)(C)C)ccc1N=Cc1ccncc1N</smiles><smiles>O=[N+]([O-])c1ccc2c(C(F)(F)F)cccc2n1</smiles> 
In the second stage, analysis of the screening data clearly reveals the phenol 4 (Figure 6) as the best aryl derivative, since it increases potency by approximately 100 -fold, though solubility is practically unchanged compared with compound 1. Interpretation of the results from the amines is less clear-cut as there is a spread of potency and solubility; students are asked to select one amine derivative each (5) to make in conjunction with the meta phenol group substituent (Figure 1). From a table of data hydroxy amines and diamines stand out as substituents that not only enhance solubility but also potency (up to 10-fold) whilst targeting an attractive logD range $(2-3.5)$. At this stage the teams prepare and deliver a presentation of their results so far and their plans for the compounds they will prepare in the laboratory.

Figure 6.

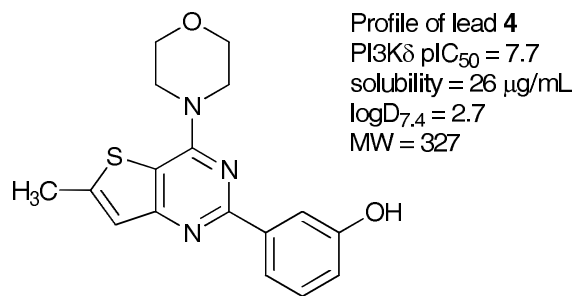

4

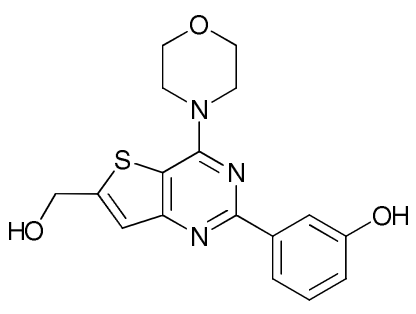

14

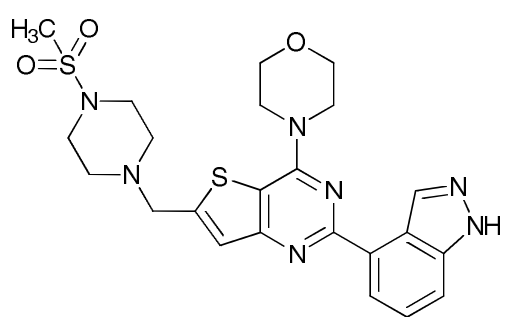

GDC-0941

Lastly, in the final workshop, the students are presented with a further challenge. They are informed that the phenol may be good for potency, but it is a group with susceptibility to rapid metabolism, so it would be prudent to prepare some bio-isosteres of the phenol. ${ }^{20,21}$ Thus, by examining the fit of a set of heterocyclic analogues in the enzyme active site, clogP values and using the Rule of Five, the students plan to make further target compounds (6) that combine the best amine and heterocyclic groups (Figure 1).

Each team then proceeds to carry out their synthesis plans in the laboratory. They have 40 hours laboratory time, spread over four weeks. During this time, each team typically attempts the preparation of around fifteen target compounds. As the teams select targets independently of each other, some targets appear in more than one team's plans.

The way in which the teams are selected and coached deserves comment. Teamwork is emphasised strongly as it is so important for success in the pharmaceutical industry. Part of one workshop is devoted to describing how effective teams are assembled. To do this we employ the Belbin Team Role questionnaire ${ }^{22}$ which helps identify preferred ways of working in teams. This allowed the students to develop increased self-knowledge and a clearer appreciation of their strengths and weaknesses, which can then feed into organisation of their presentations and laboratory activities. Each team is selected to have a blend of the nine characteristics. In addition, we take into consideration gender and academic ability. Teams are also encouraged to develop a relationship with the industrial mentors that is distinct from the usual student-academic one in which assessment provides a backdrop. Students welcome the opportunity to ask about applied research and careers in industry. Indeed, one student from the 2010 group is now employed by GSK, after completing a successful summer internship.

The section below provides a more detailed description of the chemistry. Once the compounds have been made and characterised, they are sent for screening at GSK. The results are returned to the students for incorporation into individual reports which form part of the formal assessment. The reports are about eight pages long and follow the general structure of a paper from Bioorganic and Medicinal Chemistry Letters. This gives the students the opportunity to demonstrate their 
understanding of the project, its objectives and to what extent the compounds they made moved the project towards those objectives.

\section{Target Compound Synthesis and Screening Results}

The project chemistry was designed to permit rapid synthesis of a wide range of target compounds. Thus, intermediate aldehydes $7^{23}$ and $\mathbf{1 0}^{24}$ that are not commercially available were prepared and donated by GSK. The project provides a showcase for two mechanistically important reactions frequently employed in the pharmaceutical industry: reductive amination ${ }^{25}$ and the Suzuki-Miyaura reaction ${ }^{26}$ for biaryl coupling. Preliminary investigations of the chemistry by GSK following the procedures described by Folkes et al. ${ }^{23}$ revealed some problems. Consequently, in order to give the best chance for many analogues to be completed, the students are provided with modified reaction procedures, and are not encouraged to vary them. Thus, in the reductive amination to make phenol derivatives $\mathbf{5}$, the phenol is protected with a tert-butyldimethylsilyl group as it leads to faster reactions. The reduction is achieved with sodium triacetoxyborohydride in chloroform because 1,2dichloroethane was deemed too hazardous. The various amines chosen by the students $(\mathbf{8} \mathbf{a}-\mathbf{0})$ are shown in Table 1. The intermediate $\mathbf{9}$ is desilylated, conveniently and rapidly, with ammonium fluoride ${ }^{27}$ and then purified by column chromatography to give $\mathbf{5}$. Table 1 shows the analogues prepared (with screening data).

In a similar manner, reductive amination of 10 , typically on $0.75-1.0 \mathrm{~g}$ scale, with selected amines (about three per team) gives stocks of intermediate chloropyrimidines, sufficient for several Suzuki coupling reactions with various boronic acids (11 a-I) (Figure 7) on $0.25 \mathrm{mmol}$ scale. Two sets of reaction conditions, with different palladium catalysts 12 and 13 (Figure 1) under microwave heating, can be used (for full details see Experimental Section). Conditions with conventional heating have not been investigated. The advantage of catalyst 12 is shortened reaction times. Following work-up, the products 6 are purified by column chromatography. Table 2 shows analogues prepared (with screening data).

Figure 7. Boronic acids $\left(\mathrm{HetB}(\mathrm{OH})_{2}\right)$ used in the Suzuki reaction.<smiles>OB(O)c1cccc2[nH]ncc12</smiles>

$11 \mathrm{a}$<smiles>O=C1Cc2c(cccc2B(O)O)N1</smiles>

$11 \mathrm{e}$<smiles>OB(O)c1ccc2cc[nH]c2c1</smiles>

$11 i$<smiles>Cn1ncc2c(B(O)O)cccc21</smiles>

11b<smiles>O=c1[nH]c2ccc(B(O)O)cc2[nH]1</smiles>

$11 f$<smiles>OB(O)c1ccc2nn[nH]c2c1</smiles>

11j<smiles>OB(O)c1ccc2cn[nH]c2c1</smiles>

$11 \mathrm{c}$<smiles>OB(O)c1cccc2[nH]ccc12</smiles>

$11 g$<smiles>OB(O)c1ccnc2[nH]ccc12</smiles>

$11 \mathrm{k}$<smiles>OB(O)c1cccc2cn[nH]c12</smiles>

11d<smiles>Cn1ccc2c(B(O)O)cccc21</smiles>

11h<smiles>Nc1ncc(B(O)O)cn1</smiles>

11I 
Table 1. Phenol analogues prepared, with screening results.

\begin{tabular}{|c|c|c|c|c|c|c|}
\hline Comp. & Amine $R^{1} R^{2} N-$ & $\begin{array}{c}5 \text { a-j } \\
\text { Yield }^{a}(\%)\end{array}$ & $\mathrm{plC}_{50}$ & $\mathrm{BEI}^{\mathrm{b}}$ & Solubility $^{c}$ & $\log D_{7.4}$ \\
\hline $5 a$ & & 47,21 & 6.9 & 17.4 & ++ & 2.7 \\
\hline $5 b$ & $8 b$ & $\begin{array}{c}58,53,39 \\
21,16, F\end{array}$ & 8.9 & 18.8 & +++ & 2.0 \\
\hline $5 c$ & & $59,42,33,17$ & 8.1 & 18.5 & ++ & 1.3 \\
\hline $5 d$ & $\mathrm{Me}_{2} \mathrm{NCH}_{2} \mathrm{CH}_{2} \mathrm{NMe} \mathbf{8 d}$ & $61,60,33,22$ & 7.9 & 18.5 & +++ & 1.2 \\
\hline $5 e$ & $\mathrm{HOCH}_{2} \mathrm{CH}_{2} \mathrm{NH} \mathbf{8 e}$ & $11,9, \mathrm{~F}$ & 7.6 & 19.7 & +++ & 1.2 \\
\hline $5 f$ & $\mathrm{HOCH}_{2} \mathrm{CH}_{2} \mathrm{NMe} \mathbf{8 f}$ & $\begin{array}{c}63,{ }^{\mathrm{d}} 58,{ }^{\mathrm{d}} 39,^{\mathrm{d}} \\
20, F, F, F\end{array}$ & 7.9 & 19.7 & +++ & 1.7 \\
\hline $5 g$ & $\mathrm{CH}_{3} \mathrm{CH}_{2} \mathrm{CH}_{2} \mathrm{NH} \mathbf{8 g}$ & 53 & 7.3 & 19.0 & ++ & 2.4 \\
\hline $5 h$ & $8 h$ & $69,{ }^{d} 16,9$ & 7.4 & 18.6 & ++ & 1.3 \\
\hline $5 i$ & & $24,31,39$ & 7.7 & 18.1 & ++ & 2.1 \\
\hline $5 \mathrm{j}$ & $8 \mathbf{j}$ & $57,33,10, F$ & 8.6 & 19.6 & +++ & 1.6 \\
\hline $5 k$ & & 24 & 8.2 & 17.6 & ++ & 2.3 \\
\hline 51 & $f^{N-\xi} 81$ & $78,59,51,44$ & 8.3 & 17.7 & ++ & 1.9 \\
\hline $5 m$ & ${ }^{N-\xi} 8 \mathrm{~m}$ & 40 & 8.3 & 17.2 & +++ & 1.2 \\
\hline $5 n$ & & $46^{e}$ & 7.8 & 18.3 & +++ & 1.3 \\
\hline 50 & $\mathrm{Et}^{\prime}$ \& 80 & $71^{\mathrm{e}}$ & 7.2 & 17.4 & ++ & 1.3 \\
\hline
\end{tabular}

a: Yields: each figure corresponds to a separate experiment; F corresponds to a failed reaction in which no product was successfully isolated following chromatography. All compounds are solids and were characterised by melting point, ${ }^{1} \mathrm{H}$ NMR and IR spectroscopy. In addition, all compounds tested by GSK underwent quality assessment by LC-MS and all were determined to be $\geq 90 \%$ pure. ${ }^{\text {b}}: \mathrm{BEI}=$ binding efficiency index $=\mathrm{pIC}_{50} \times$ 1000 / MW, see Abad-Zapatero, C.; Expert Opin. Drug Discov. 2007, 2, 469-488. ' : Compounds were ranked as $+++($ soluble, $>100 \mu \mathrm{g} / \mathrm{mL})$, ++ (poorly soluble, $10-100 \mu \mathrm{g} / \mathrm{mL}$ ), and + (very insoluble, $<10 \mu \mathrm{g} / \mathrm{mL}$ ). ${ }^{\mathrm{d}}$ : Yield improved by using 5 equivalents of amine. ${ }^{\text {e. }}$ Reductive aminations were performed with 2-(N-Bocaminomethyl)pyrrolidine (8n) and N-Boc-N'-ethyl-1,2-diaminoethane (8o). After desilylation and purification, the Boc group was removed by treatment with $4 \mathrm{~N}$ hydrogen chloride in dioxane at $0{ }^{\circ} \mathrm{C}$. 
Table 2: Heterocyclic analogues prepared with screening results.

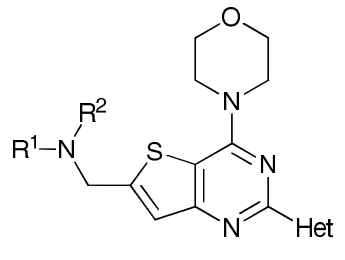

6

\begin{tabular}{|c|c|c|c|c|c|c|c|}
\hline Comp. & $\mathrm{R}^{1} \mathrm{R}^{2} \mathrm{NH}$ & Het & Yield \% ${ }^{a}$ (Method) & $\mathrm{plC}_{50}$ & $\mathrm{BEl}^{\mathrm{b}}$ & Solubility $^{\mathrm{C}}$ & $\log D_{7.4}$ \\
\hline $6 a$ & $8 a$ & $11 a$ & $5(\mathrm{~A})$ & 6.9 & 16.4 & ++ & NA \\
\hline \multirow{4}{*}{$6 b$} & \multirow{4}{*}{$8 b$} & \multirow{4}{*}{$11 a$} & $78(\mathrm{~A})$ & & & & \\
\hline & & & $31(\mathrm{~A})$ & 7.8 & 15.9 & ++ & 2.0 \\
\hline & & & $57(\mathrm{~B})$ & & & & \\
\hline & & & $20(\mathrm{~B})$ & & & & \\
\hline \multirow{3}{*}{$6 c$} & \multirow{3}{*}{$8 c$} & \multirow{3}{*}{$11 a$} & $52(\mathrm{~A})$ & & & & \\
\hline & & & $58(\mathrm{~A})$ & 7.5 & 16.7 & +++ & 1.3 \\
\hline & & & $8(\mathrm{~A})$ & & & & \\
\hline \multirow{3}{*}{$6 d$} & \multirow{3}{*}{$8 d$} & \multirow{3}{*}{$11 a$} & $45(\mathrm{~A})$ & & & & \\
\hline & & & $27(\mathrm{~A})$ & 7.1 & 15.7 & ++ & 1.3 \\
\hline & & & $13(\mathrm{~A})$ & & & & \\
\hline \multirow{3}{*}{$6 e$} & \multirow{3}{*}{$8 f$} & \multirow{3}{*}{$11 a$} & $50(\mathrm{~A})$ & & & & \\
\hline & & & $42(\mathrm{~A})$ & 6.9 & 16.2 & ++ & 1.7 \\
\hline & & & $12(\mathrm{~B})$ & & & & \\
\hline $6 f$ & $8 \mathrm{~h}$ & $11 a$ & $51(\mathrm{~A})$ & 6.4 & 15.2 & ++ & 1.4 \\
\hline \multirow{2}{*}{$6 \mathrm{~g}$} & \multirow{2}{*}{$8 i$} & \multirow{2}{*}{$11 a$} & $21(\mathrm{~B})$ & 7.7 & 15.6 & +++ & 2.0 \\
\hline & & & $8(\mathrm{~B})$ & & & & \\
\hline \multirow{3}{*}{$6 h$} & \multirow{3}{*}{$8 \mathbf{j}$} & \multirow{3}{*}{$11 a$} & $41(\mathrm{~A})$ & 7.7 & 16.4 & ++ & 1.7 \\
\hline & & & $8(\mathrm{~B})$ & & & & \\
\hline & & & $5(\mathrm{~A})$ & & & & \\
\hline \multirow{2}{*}{$6 \mathbf{i}$} & \multirow{2}{*}{81} & \multirow{2}{*}{$11 a$} & $8(\mathrm{~B})$ & 7.8 & 15.8 & +++ & 2.0 \\
\hline & & & $22(\mathrm{~B})$ & & & & \\
\hline $6 j$ & $8 \mathbf{b}$ & $11 b$ & $37(\mathrm{~B})$ & 6.6 & 13.0 & +++ & 2.6 \\
\hline \multirow{2}{*}{$6 k$} & $8 i$ & $11 \mathrm{~h}$ & $9(\mathrm{~A})$ & 6.2 & 13.3 & ++ & 2.2 \\
\hline & & & $F(A)$ & & & & \\
\hline 61 & $8 a$ & 11c & $27(\mathrm{~A})$ & 5.4 & 12.9 & + & 2.7 \\
\hline $6 m$ & $8 j$ & 11c & $F(A)$ & & & & \\
\hline $6 n$ & $8 b$ & 11d & $53(\mathrm{~A})$ & 6.8 & 13.8 & + & 2.9 \\
\hline 60 & $8 c$ & 11d & $F(A)$ & & & & \\
\hline $6 p$ & $8 j$ & 11d & $10(\mathrm{~A})$ & 6.4 & 13.8 & ++ & 2.6 \\
\hline $6 q$ & $8 b$ & $11 \mathrm{e}$ & $24(\mathrm{~A})$ & 6.2 & 12.2 & +++ & 1.7 \\
\hline $6 r$ & $8 c$ & $11 \mathrm{e}$ & $F(A)$ & & & & \\
\hline $6 s$ & $8 d$ & $11 \mathrm{e}$ & 15 & 5.8 & 12.4 & +++ & 1.1 \\
\hline & & & $13(\mathrm{~A})$ & & & & \\
\hline & & & $79(\mathrm{~A})$ & & & & \\
\hline $6 t$ & $8 j$ & $11 \mathrm{e}$ & 19 (B) & 6.3 & 13.2 & +++ & 1.5 \\
\hline & & & 39 (B) & & & & \\
\hline & & & $F(A)$ & & & & \\
\hline $6 u$ & 81 & $11 \mathrm{e}$ & $30(\mathrm{~B})$ & 6.1 & 12.9 & +++ & 1.7 \\
\hline $6 v$ & $8 c$ & $11 \mathrm{f}$ & $F(A)$ & & & & \\
\hline $6 w$ & $8 j$ & $11 f$ & $59(\mathrm{~A})$ & $<4.5$ & $<9.6$ & +++ & NA \\
\hline $6 x$ & $8 c$ & $11 \mathrm{~g}$ & $F(A)$ & & & & \\
\hline $6 v$ & $8 d$ & 11 & $27(\mathrm{~A})$ & 6.9 & 15.3 & + & 1.6 \\
\hline & & 119 & $F(A)$ & & & & \\
\hline $6 z$ & $8 j$ & $11 \mathrm{~g}$ & $F(A)$ & & & & \\
\hline
\end{tabular}




\begin{tabular}{|c|c|c|c|c|c|c|c|}
\hline 6aa & $8 c$ & $11 \mathrm{~h}$ & $5(\mathrm{~A})$ & 6.6 & 13.9 & +++ & 2.6 \\
\hline 6ab & $8 a$ & $11 i$ & $F(A)$ & & & & \\
\hline \multirow{2}{*}{ 6ac } & \multirow{2}{*}{$8 b$} & \multirow{2}{*}{$11 i$} & $15(\mathrm{~B})$ & 6.3 & 12.8 & ++ & 2.6 \\
\hline & & & $7(\mathrm{~A})$ & & & & \\
\hline 6ad & $8 c$ & $11 i$ & $29(\mathrm{~A})$ & 6.2 & 13.4 & +++ & 1.9 \\
\hline \multirow{2}{*}{ 6ae } & \multirow{2}{*}{$8 d$} & \multirow{2}{*}{$11 i$} & $48(\mathrm{~A})$ & 7.1 & 15.8 & ++ & NA \\
\hline & & & $9(\mathrm{~A})$ & & & & \\
\hline 6af & $8 h$ & $11 i$ & $23(\mathrm{~A})$ & 5.5 & 13.0 & ++ & 1.9 \\
\hline 6ag & $8 j$ & $11 \mathrm{i}$ & $14(\mathrm{~A})$ & 6.0 & 13.0 & ++ & 2.3 \\
\hline 6ah & 81 & $11 \mathrm{i}$ & $11(\mathrm{~B})$ & 5.9 & 12.0 & +++ & 2.6 \\
\hline 6ai & $8 m$ & $11 i$ & $2(\mathrm{~B})$ & 5.9 & 11.7 & +++ & NA \\
\hline 6aj & $8 b$ & $11 \mathrm{j}$ & $F(A)$ & & & & \\
\hline 6ak & $8 \mathrm{j}$ & $11 \mathrm{j}$ & $F(A)$ & & & & \\
\hline 6al & $8 d$ & $11 \mathrm{k}$ & $18(\mathrm{~A})$ & 6.7 & 14.9 & +++ & 1.1 \\
\hline 6am & $8 f$ & $11 \mathrm{k}$ & $50(\mathrm{~A})$ & 5.5 & 13.0 & +++ & 1.7 \\
\hline 6an & $8 \mathrm{~h}$ & $11 \mathrm{k}$ & $8(\mathrm{~A})$ & 6.1 & 14.5 & ++ & 1.1 \\
\hline $6 a o$ & $8 d$ & 111 & $8(\mathrm{~A})$ & 7.7 & 18.0 & +++ & 0.6 \\
\hline 6ap & $8 c$ & $11 I$ & $9(\mathrm{~A})$ & 7.9 & 18.0 & ++ & 0.7 \\
\hline 6aq & $8 f$ & $11 I$ & $8(\mathrm{~A})$ & 7.2 & 18.0 & ++ & 1.0 \\
\hline
\end{tabular}

a: Yields: each figure corresponds to a separate experiment; F corresponds to a failed reaction in which no product was successfully isolated following chromatography. All compounds are solids and were characterised by melting point, ${ }^{1} \mathrm{H}$ NMR and IR spectroscopy. In addition, all compounds tested by GSK underwent quality assessment by LC-MS and all were determined to be $\geq 90 \%$ pure. ${ }^{\mathrm{b}}: \mathrm{BEI}=$ binding efficiency index $=\mathrm{plC}_{50} \times$ 1000 / MW. ${ }^{c}$ : Compounds were ranked as +++ (soluble, $\left.>100 \mu \mathrm{g} / \mathrm{mL}\right),++($ poorly soluble, $10-100 \mu \mathrm{g} / \mathrm{mL}$ ), and + (very insoluble, $<10 \mu \mathrm{g} / \mathrm{mL}$ ).

To ensure experiments are conducted safely, the following precautions are taken. Students wear standard personal protective equipment (lab coats, safety spectacles and gloves) and conduct all reactions and work-ups in a fumecupboard. The hazards associated with the aldehydes $\mathbf{7}$ and $\mathbf{1 0}$ and boronic acids have not been established, but standard precautions are adequate to limit exposure. The hazards associated with the other chemicals are listed in the Experimental. Certain chemicals, particularly dioxane and chloroform, are undesirable owing to their toxicity and environmental impact, and efforts are being made to eliminate them through modification of the experimental protocols. Demonstrators instruct the students in setting up the Suzuki reactions in microwave vials, in particular to ensure all solids are below the level of the solvent. The demonstrators are responsible for sealing the vials and operating the microwave reactors.

\section{Resources}

GSK committed substantial resources in setting up the course. These included selecting the appropriate live in-house programme, the appropriate molecular template for inhibiting PI3K $\delta$ which allowed iterative cycles of medicinal chemistry, choreographing the iterations to fit the time available, development of robust synthetic chemistry procedures and purification protocols, bulk synthesis of intermediates for the students to use, the synthesis and testing of large numbers of compounds so that data can be rapidly provided to the students after various iterations, the preparation of material to be taught in workshop modules, molecular modelling visualisations of potential targets in the active site, data analysis visualisation plots, and multiple visits for mentoring the students. Each GSK mentor for example, spent approximately 1-2 weeks preparing and then another week teaching and mentoring. To date, over 20 employees at GlaxoSmithKline in Stevenage have contributed.

\section{Discussion}

Extensive informal feedback was obtained from the students through individual conversations. They particularly appreciated the problem-based approach, especially as it so sharply contrasted with their laboratory experience from the previous year. Other aspects that drew favourable comments were 
that theory was linked to practice and a real-life problem, and the significant input from scientists from industry. The students found the team skills training interesting and not like anything they had experienced before - they discovered that success is not just about academic ability - which gave personal insights into what qualities potential employers might expect. It was interesting to observe that, despite the process to assign students to teams, not all teams performed equally well. Those that did some planning ahead of each practical session (independently of a tutor or demonstrator) were generally better organised and able to make the best use of their time in the laboratory. Aspects of the course workshops, such as discussion and practicing concepts (calculating hydrophobicities, molecular modelling) immediately helped cement learning.

The following are quotes from students, taken from the University's Student Evaluation of Module and Teaching forms.

"The best part of the module was being taught by people who have extensive experience in the pharmaceutical industry; this was beneficial as they often related new material to projects they had worked on previously."

"I really enjoyed how the module combined everything we had learnt in lectures to allow us to see and be part of the drug discovery process. I believe it gave a real insight into medicinal chemistry/pharmaceutical industry, through practical drug development and seeing how drugs get to market, and showed us what we could achieve after leaving university. I thoroughly enjoyed the module and would recommend it to any aspiring medicinal chemist."

"What I liked about the GSK module is that it brought my degree into practice and helped bring the pharmacological aspects that we had studied together with the chemistry. I think the module could have been improved by having more time in the design process of compounds."

"Really enjoyable module, made me want to do my $4^{\text {th }}$ year project in medicinal chemistry."

"Very engaging, lots of advice and support, excellent notes, good fun."

"Free-thinking encouraged."

"The interactive workshops challenged thought processes."

"It allows me to put the theory learnt into practice. Conducted in small groups increasing teamwork and communication skills."

"Made you think. Relevant to drug design."

"Loved having actual researchers from industry, made the module interesting and enjoyable."

"I like the variety of assessments types. I think the link with the lab modules is very good because it enables a better idea of the practical issues facing medicinal chemists."

"The workshops were well structured and encouraged participation. The relevance to the real world also helped retain my interest."

"I enjoy working in a team, and it was nice working with people I haven't worked with before. It was also really good having speakers coming in from GSK and the mentors were brilliant at providing assistance and willing to answer questions." 
What has the GSK staff learnt and how do they feel they have benefited? Several clear themes emerge:

- Most GSK staff particularly enjoyed the interactions with the students. Several of the GSK mentors felt they developed more effective time management skills based on juggling both their GSK and Nottingham workloads.

- Many were struck by the challenge of delivering the aims of the module to inexperienced students in the very limited timeframe. Other challenges included (i) preparing (and sometimes relearning!) the teaching material at the right level, (ii) requiring the students to prepare pure, characterised and some cases novel compounds for test and (iii) learning how to coach the student teams in decision making, and to manage group dynamics.

- Thinking about the best way to present the results from the various iterations to the students also made one mentor think carefully about how to present data most effectively at GSK.

- Everyone involved from GSK was surprised how clearly the course aims and scope were expected to be. For example, it was essential that examinable and non-examinable material was made explicit.

\section{Chemistry achievements and challenges}

Considering the scientific achievements of the course, most of the experiments were successful, and students were able to isolate good quality samples. Some of the yields were rather low, which was probably due to student inexperience. Failures in the reductive aminations could be attributed to difficulties in dispensing accurately small quantities of liquid amines (Gilson pipettes were used), and the unreactive nature of some of the amines (particularly the amino alcohols). The main side product was the primary alcohol 14 (Figure 6), which sometimes misled students into thinking this was the desired product, though NMR readily identified it. Yields for the reductive aminations on 2-3 mmol scale were invariably higher than those on $0.3 \mathrm{mmol}$. The literature suggests improved yields might be expected with sodium cyanoborohydride in methanol, ${ }^{28}$ but this was considered too hazardous for undergraduates. The first time the project was run, some protected diamines e.g. 8n, 80 were included. While the reactions worked, the extra step involved in removing the protection made the overall procedure very long, though feasible for more able students. Some of the students responded very positively to the challenge of a failed reaction and discussed how conditions might be altered before putting the reaction on again. Exposure to industry-standard equipment (microwave reactors, automated chromatography) and methodology was welcomed.

The ${ }^{1} \mathrm{H}$ NMR spectra of the target compounds were challenging to interpret due to three features sometimes present. Firstly, the relatively slow bond rotation of the morpholine ring (and piperazine ring, where present) sometimes caused signal broadening. Signal broadening was also observed with the hydrochloride salts of certain derivatives. Finally, derivatives of the tertiary amide $\mathbf{8 b}$ displayed two sets of signals in an unequal ratio owing to slow rotation about the amide bond. Most of the students were unfamiliar with these concepts from their lecture courses.

The two methods for the Suzuki coupling worked as well as each other; catalyst $\mathbf{1 2}$ is more active but also more expensive than 13. More failures were observed than with the reductive amination: they seemed to be more related to the boronic acid selected, though this was difficult to be sure about.

On average each student performed five reactions, three chromatographic separations, and succeeded in making two test compounds. The students' medicinal chemistry reports were generally very well written, demonstrating good understanding of the project objectives, though some had difficulty with correct use of the scientific terminology and ensuring accurate drawing of chemical structures.

Some of the compounds possessed significantly improved profiles compared with compound 4 ( $\mathrm{plC}_{50}$ $=7.7$ ). In particular, the pyrrolidines $\mathbf{5 b}$ and $\mathbf{5 c}$, and piperazines $\mathbf{5 j}-\mathbf{5 m}$ combined $\mathrm{plC}_{50}$ values $>8$ 
with much improved aqueous solubility and reduced lipophilicity $(\log D$ in the range $1.3-2.3)$. The best of these was the tertiary amide $\mathbf{5 b}$, although $\mathbf{5} \mathbf{j}$ has the best combination of potency and binding efficiency index. It is of note that $\mathbf{5} \mathbf{f}$ is almost as potent and has the equal highest BEI, suggesting that derivatives might be worth investigation. From the wide range of phenol bioisosteres examined, the ones with a $1 \mathrm{H}$-indazol-4-yl group, in combination with the preferred amines $(\mathbf{6 b}, \mathbf{6 c}, \mathbf{6} \mathbf{h}$ and $\mathbf{6 i})$ were clearly the most potent, though none of them could quite match the potency of the corresponding phenols. However, good aqueous solubility was achieved whilst maintaining a druglike $\log \mathrm{D}$. Only one $1 \mathrm{H}$-indol-4-yl analogue (6y) was prepared successfully, and possessed similar potency to $\mathbf{6 d}$, suggesting that further analogues should be made. However, azaindoles 6al-6an were disappointing. In contrast, compounds based on isomeric indazoles (11c, 11d) or N-methyl heterocycles (11b, 11h) possessed modest potency and were also some of the most lipophilic compounds made $\left(\log \mathrm{D}_{7.4}>2.5\right)$. Very interesting results were obtained with the aminopyrimidines 6ao and 6ap, which achieved good potency and BEl at very low lipophilicity. Incorporation of this heterocycle into further derivatives would permit a search for more potency through more lipophilic amines, without departing from the ideal logD range or increasing the molecular weight beyond 500 , as has recently been described by Genentech-Piramed. ${ }^{29}$

It is interesting that, as yet, none of the students have proposed making GDC-0941 (Figure 6), ${ }^{23}$ which was the PI3K $\alpha$ inhibitor taken into development. This is because the sulfonylpiperazine does little to improve aqueous solubility and is thus an unattractive choice of amine. GDC-0941 also breaks Lipinski's molecular weight rule and has ten hydrogen bond acceptors. What cannot be predicted is that, whereas the $1 \mathrm{H}$-indazol-4-yl compound in most cases is less potent than the corresponding phenol analogues, in the case of the sulfonylpiperazine analogue potency is fully retained. ${ }^{23,30}$

\section{Conclusions}

The development of a practical medicinal chemistry course, suitable for third-year undergraduates, has been described. Students have learnt about balancing three important properties - potency, solubility and lipophilicity - and have successfully designed more potent and soluble analogues such as $5 \mathrm{~b}, 5 \mathrm{j}, 6 \mathrm{~b}, 6 \mathrm{c}, 6 \mathrm{~h}, 6 \mathrm{i}, 6 \mathrm{ao}$ and $6 \mathrm{ap}$.

It is evident that other universities may not be able to reproduce this project without the same level of funding, access to equipment and screening facilities. However, one might be able to take it as a template, consisting of:

- An enzyme target with a published X-ray crystal structure, with a way to conduct molecular modelling and docking of target compounds.

- A simple assay for enzyme inhibitors with commercially available enzyme and fluorogenic substrate. Aqueous solubility can be measured by eye (turbidometric method), and the hydrophobicity index requires access to an analytical hplc with reverse-phase column.

- A lead chemical series with opportunities for derivatisation through 1-3 chemical steps. Key intermediates should be commercially available or readily synthesised.

Since the current module is limited to eighteen chemistry students, consideration is now being given to devising alternative projects that would be less expensive, less reliant on industry support (e.g. for intermediates and compound screening), and potentially open to more students.

\section{Experimental}

General experimental. Spectroscopic data were recorded on Bruker Tensor $27 \mathrm{IR}$ and Bruker AV400 ( ${ }^{1} \mathrm{H}$ NMR $\left.400 \mathrm{MHz}\right)$, Bruker DPX300 ( ${ }^{1} \mathrm{H}$ NMR $\left.300 \mathrm{MHz}\right)$, Jeol EX270 ( ${ }^{1} \mathrm{H}$ NMR $270 \mathrm{MHz}$ ) instruments. All reactions were conducted under a positive pressure of dry nitrogen unless stated otherwise. Amines $8 \mathrm{a}-\mathrm{m}$ and boronic acids 11a-I were obtained from commercial sources. Amines 
$8 \mathrm{n}$ and $\mathbf{8 0}$ were purchased as their N-Boc derivatives. Compounds $\mathbf{7}$ and $\mathbf{1 0}$ were prepared by GSK according to the methods of Folkes et al. ${ }^{23}$ Palladium catalysts 12 and 13 were purchased from Sigma-Aldrich and Alfa Aesar, respectively. Column chromatography was performed on silica gel or aminopropyl-modified silica gel (Biotage Isolute ${ }^{\mathrm{TM}}$ or SNAP ${ }^{\mathrm{TM}}$ cartridges) with a Jones Chromatography Flashmaster II automated system. Kieselgel $60 \mathrm{~F}_{254}$ plates from E. Merck and aminopropyl-modified plates from Biotage were used for TLC, and compounds were visualised using u.v. light, anisaldehyde solution or $0.5 \%$ aqueous potassium permanganate solution. Petrol refers to petroleum ether (bp $40-60^{\circ} \mathrm{C}$ ) unless stated otherwise.

\section{Hazards}

Chloroform is an irritant and harmful if ingested. It also is a cancer suspect agent in humans (IARC class $2 \mathrm{~B}$ ). Dioxane is an irritant, highly flammable, may form explosive peroxides. It also is a cancer suspect agent. Acetic acid is corrosive and flammable. Ethanol is flammable. Toluene is flammable and an irritant and may cause lung damage if ingested. It is also a potential teratogen. Sodium triacetoxyborohydride may liberate hydrogen gas in the presence of water. Ammonium fluoride is toxic on skin contact, inhalation or if ingested. Potassium phosphate is a skin irritant and may cause serious eye damage. The various amines used in the project are flammable and corrosive - further information on their hazards may be obtained from commercial suppliers. The palladium catalysts, 2(dimethylaminomethyl)ferrocen-1-yl-palladium (II) chloride dinorbornylphosphine complex (12) and $\mathrm{PdCl}_{2}\left(\mathrm{PPh}_{3}\right)_{2}$ (13), do not have hazards listed - however, they should be assumed to be toxic.

Procedure for reductive amination of aldehyde (7) followed by desilylation. 2-(3-((Tertbutyldimethylsilyl)oxy)phenyl)-4-morpholinothieno[3,2-d]pyrimidine-6-carbaldehyde (152 mg, 0.33 $\mathrm{mmol}$ ) was dissolved in chloroform $(5 \mathrm{~mL})$ under nitrogen at room temperature. The amine 8 (0.66 $\mathrm{mmol}$ ) and acetic acid $(0.5 \mathrm{M}$ in chloroform, $1.32 \mathrm{~mL}, 0.66 \mathrm{mmol})$ were added and the resulting solution was stirred for $15-30$ minutes. Sodium triacetoxyborohydride $(210 \mathrm{mg}, 0.99 \mathrm{mmol})$ was then added as a solid in one portion, and the reaction mixture was stirred until tlc indicated complete reaction (between $30 \mathrm{~min}$ and $16 \mathrm{~h}$ ). Saturated aqueous sodium bicarbonate $(10 \mathrm{~mL})$ was added to the solution and the organic layer separated. The aqueous layer was extracted with chloroform (10 $\mathrm{mL}$ ) and the combined organic solutions were dried $\left(\mathrm{MgSO}_{4}\right)$ and concentrated under reduced pressure to give the crude amine silyl ether 9 .

The crude silyl ether 9 (assumed to be pure, 1.0 equiv.) was treated with a solution of ammonium fluoride (5.0 equiv.) in methanol $(5-10 \mathrm{~mL} / \mathrm{mmol}$ silyl ether) under nitrogen at room temperature. The mixture was stirred until tlc indicated complete reaction (typically $<30 \mathrm{~min}$ ). The solvent was removed under reduced pressure and the residue was taken up in 1-2 $\mathrm{ml}$ dichloromethane (some ammonium fluoride did not dissolve). The solution was then applied to the top of a Biotage Isolute ${ }^{\mathrm{TM}}$ silica gel cartridge $(20 \mathrm{~g})$ and eluted using the Flashmaster apparatus (gradient elution with hexane/ethyl acetate/methanol/triethylamine or dichloromethane/methanol/ammonia). Fractions containing product were identified by tlc, and evaporated under reduced pressure to give the product. For those products that were not obtained as solids, treatment with a small volume of hot ethyl acetate and scratching caused the product to crystallize. The suspension was filtered and dried to give the desired product 5 .

Alternatively, the desilylation step could be performed by using a solution of tetrabutylammonium fluoride in THF (1.1 eq.) at room temperature.

For those amines that were purchased as the hydrochloride salts, the acetic acid was omitted and replaced by a molar equivalent amount of anhydrous sodium acetate.

Data for 6-hydroxymethyl-2-(3-hydroxyphenyl)-4-morpholinothieno[3,2-d]pyrimidine (compound 14): ${ }^{1} \mathrm{H}$ NMR $\left(270 \mathrm{MHz}, \mathrm{DMSO}-\mathrm{d}_{6}\right) \delta_{\mathrm{H}} 9.49(1 \mathrm{H}, \mathrm{s}), 7.84(1 \mathrm{H}, \mathrm{s}), 7.83(1 \mathrm{H}, \mathrm{d}, \mathrm{J} 8 \mathrm{~Hz}), 7.31(1 \mathrm{H}, \mathrm{s}), 7.26$ 
(1H, t, J $8 \mathrm{~Hz}), 6.24(1 \mathrm{H}, \mathrm{d}, \mathrm{J} 8 \mathrm{~Hz}), 5.91(1 \mathrm{H}, \mathrm{t}, \mathrm{J} 5.7 \mathrm{~Hz}), 4.85(2 \mathrm{H}, \mathrm{d}, \mathrm{J} 5.7 \mathrm{~Hz}), 3.98(4 \mathrm{H}, \mathrm{m}), 3.80$ $(4 \mathrm{H}, \mathrm{m})$.

\section{Preparation of heterocyclic derivatives (6) via Suzuki reaction.}

The procedure for reductive amination of chloropyrimidine (10) is the same as above, omitting the desilylation step, but was generally conducted on $2.5-3.5 \mathrm{mmol}$ scale.

Suzuki reaction Method A: The chloropyrimidine ( $0.25 \mathrm{mmol}, 1.0$ equiv.), boronic acid (11) (0.375$0.5 \mathrm{mmol}$ ), and potassium phosphate (3.0 equiv.) were weighed into a microwave vial equipped with a stir-bar at room temperature. The catalyst, 2-(dimethylaminomethyl)ferrocen-1-yl-palladium (II) chloride dinorbornylphosphine complex ( 0.1 equiv.) was added. Then a mixture of dioxane and water $(2: 1,4 \mathrm{ml} / \mathrm{mmol}$ of chloropyrimidine) was added carefully and the vial was flushed with nitrogen. The vial was sealed and heated in a microwave reactor for $10 \mathrm{~min}$ at $140^{\circ} \mathrm{C}$. The cooled reaction mixture was sampled by tlc (silica gel and aminopropyl silica gel) and if the reaction was not complete, another 1 equiv. boronic acid/ester added, and reaction continued for another $10-20 \mathrm{~min}$ at $140^{\circ} \mathrm{C}$. The mixture was filtered through a pad of kieselguhr, washing with ethyl acetate $(10 \mathrm{ml})$. The filtrate was washed with saturated aqueous sodium bicarbonate $(5 \mathrm{~mL})$, dried $\left(\mathrm{MgSO}_{4}\right)$ and the solvent was removed under reduced pressure. The residue was taken up in $\sim 1 \mathrm{~mL}$ dichloromethane and applied to the top of an aminopropyl silica gel cartridge (10 or $20 \mathrm{~g}$ ) and eluted using the Flashmaster apparatus (gradient elution with hexane/ethyl acetate/methanol; typically $0-100 \%$ ethyl acetate in hexane over $15 \mathrm{~min}$ followed by $0-15 \%$ methanol in ethyl acetate over $15 \mathrm{~min}$, flow rate $15-20$ $\mathrm{mL} / \mathrm{min}$ ). Fractions containing product were identified by tlc, and evaporated under reduced pressure to give the product as a gum. Treatment with a small volume of hot ethyl acetate and scratching caused the product to crystallize. The suspension was filtered and dried to give the desired product (6). Occasionally, products that refused to crystallise were converted to their hydrochloride salts in order to obtain a solid sample.

Suzuki reaction Method B: The chloropyrimidine ( $0.22 \mathrm{mmol}, 1.0$ equiv.), boronic acid (11) (0.44 $\mathrm{mmol})$, and sodium carbonate $(0.77 \mathrm{mmol}, 3.5$ equiv.) were weighed into a microwave vial equipped with a stir-bar at room temperature. The catalyst, bis(triphenylphosphine)palladium (II) chloride (0.02 mmol, 0.1 equiv. ) was added. Then toluene $(1.2 \mathrm{~mL})$, ethanol $(0.6 \mathrm{~mL})$ and water $(0.3 \mathrm{~mL})$ were added carefully and the vial was flushed with nitrogen. The vial was sealed and heated in a microwave reactor for $90 \mathrm{~min}$ at $130^{\circ} \mathrm{C}$. Work-up and purification was as described above.

\section{Compound assays}

Methods for measuring PI3K $\delta$ inhibitor potency, aqueous solubility and $\log \mathrm{D}$ by hplc are described in references 17-19, respectively.

\section{Acknowledgements}

MJF wishes to thank GlaxoSmithKline for their extremely generous support of this work: for presentation of medicinal chemistry workshops including provision of molecular models of putative target compounds in the PI3K $\delta$ active site; for the loan of a Flashmaster ${ }^{\mathrm{TM}}$ II automated chromatography system, Biotage Initiator ${ }^{\mathrm{TM}}$ and Emrys Optimiser ${ }^{\mathrm{TM}}$ microwave reactors, and for funding consumables associated with the project. We are grateful to Sarah Smith and James Rowedder for kinase assay data, and Alan Hill, Shenaz Bunally and Sylvia Bardoni for physicochemical data. We also thank the Chemical Computing Group, Montreal, Quebec, Canada, who provided licences for the Molecular Operating Software free of charge. We acknowledge Prof. Christopher Moody for his help and advice when setting up the project. We also wish to thank Trevor Farren, Malcolm Skingle and Julia Florence for facilitating the financial and legal arrangements and Tricia Lucas-Clarke for administrative assistance. We are grateful to industrial placement students Elvis Maduli, Nicola Kellichan, Jonathan Ferrier, and Craig Donoghue, who trialled most of the chemistry. The authors also wish to thank the 46 students who participated in and contributed so fully 
to the project so far: James Adams, Charlotte Bailey, Joshua Britton, Kerry Burnett, Joshua Burton, Edward Cannons, Chantal Carlstein-Finn, Ryan Chiu, Christopher Clarke, Peter Cleaves, Gabrielle Delcuratolo, Tim Douglas, Natasha Eccles, Emily Elsey, Heidi Fisk, William Gower, Danielle Harvey, Joshua Haye, Paul Henry, Nick Herbert, Christian Hoenig, Jason Hood, Callum Hook, Dominic Howgego, Jack Humby, Danielle Jex, Alice Johnson, Joe Jones, Rebecca Kirk, Anil Parmar, James Quinn, Andrew Rawlings, William Restorick, John Ritchie, Hannah Russell, Thomas Sanderson, Imandeep Sehmbi, Christopher Seymour, Christopher Smedley, Jack Sorrell, Robert Straker, Bradley Thomas, Megan Thomsett, Tom Tongue, Jack Turner, and Charlotte Wood.

\section{References}

1. McDonnell, C.; O'Connor, C.; Seery, M.K.; Chem. Educ. Res. Pract., 2007, 8, 130-139.

2. Flynn, A.B.; Biggs, R.; J. Chem. Ed., 2012, 89, 52-57.

3. Cannon, K.C.; Krow, G.R.; J. Chem. Ed., 1998, 75, 1259-60.

4. Reid' N.; Shah' I.; Chem. Educ. Res. Pract., 2007, 8, 172-185.

5. Russell, C.B.; Weaver, C.G.; Chem. Educ. Res. Pract., 2011, 12, 57-67.

6. New projects currently being trialled at the School of Chemistry will be reported elsewhere.

7. Domin, D.S.; J. Chem. Ed., 1999, 76, 543-547.

8. Kelly, O.C.; Finlayson, O.E.; Chem. Educ. Res. Pract., 2007, 8, 347.

9. Hanson, S.; Overton, T.; Skills required by new chemistry graduates and their development in degree programmes. Report from the Higher Education Academy, UK Physical Sciences Centre, University of Hull, UK. http://www.heacademy.ac.uk/assets/documents/subjects/ps/chemistry-graduate-skills.pdf (accessed June 20th, 2013)

10. Ito, K.; Caramori, G.; Adcock, I.M.; J. Pharm. Exp. Ther., 2007, 321, 1-8.

11. Wu, P.; Hu, Y.; MedChemComm., 2012, 3, 1337.

12. Patrick, G., An Introduction to Medicinal Chemistry, $4^{\text {th }}$ Ed., Oxford University Press, Oxford, U.K., 2009, Chapter 13, p 212-241.

13. Lipinski, C.A.; Lombardo, F.; Dominy, B.W.; Feeny, P.J.; Adv. Drug. Del. Rev., 1997, 23, 3-25.

14. MOE (Molecular Operating Environment) is a suite of drug discovery software sold by Chemical Computing Group, Montreal, Quebec, Canada, see http://www.chemcomp.com/ (accessed June 20th, 2013).

15. Walker, E.H.; Pacold, M.E.; Perisic, O.; Stephens, L.; Hawkin, P.T.; Wymann, M.P.; Williams, R.L.; Mol Cell, 2000, 6, 909-919. For X-ray crystal structures of PI3K $\delta$ and inhibitors, see Berndt, A.; Miller, S.; Williams, O.; Le, D.D.; Houseman, B.T.; Pacold, J.I.; Gorrec, F.; Hon, WC.; Ren, P.; Liu, Y.; Rommel, C.; Gaillard, P.; Rückle, T.; Schwarz, M.K.; Shokat, K.M.; Shaw, J.P.; Williams, R.L.; Nature Chem. Biol., 2010, 6, 117-124. Protein Data Bank structure number $2 \mathrm{WXP}$.

16. Spotfire is a data analysis tool from TIBCO Spotfire, 212 Elm Street, Somerville, MA 02144 , U.S.A. http://spotfire.tibco.com/en/discover-spotfire.aspx (accessed June 20th, 2013). The compounds of the amine array were plotted according to clogP (X-axis), molecular weight ( $\mathrm{Y}$ axis) and each colour- and shape-coded according to the number of hydrogen bond acceptors and donors, respectively (see Supplementary Material, Figure 1).

17. Degorce, F.; Card, A.; Soh, S.; Trinquet, E.; Knapik, G. P.; Xie, B.; Curr. Chem. Genomics, 2009, 3, 26.

18. Bhattachar, S.N.; Wesley, J.A.; Seadeek, C.; J. Pharm. Biomed. Anal., 2006, 41, 153. Solubility was measured by a turbidometric (precipitative) method. The compound (10mM in DMSO) is added to aqueous buffer ( $\mathrm{pH} 7.4)$, sample was then centrifuged and the concentration of compound measured in the supernatant by quantitative Chemiluminescent Nitrogen Detection (CLND). Compounds were ranked as +++ (soluble, $>100 \mu \mathrm{g} / \mathrm{mL}),++$ (poorly soluble, $10-100 \mu \mathrm{g} / \mathrm{mL}$ ), and + (very insoluble, $<10 \mu \mathrm{g} / \mathrm{mL}$ ). 
19. LogD was measured by a reverse-phase chromatographic method as described by Giaginis, C.; Tsantili-Kakoulidou, A.; J. Liq. Chromatog. Rel. Tech., 2008, 31, 88. See also Valkó, K.; J. Chromatog. A, 2004, 1037, 299-310.

20. Patrick, G., An Introduction to Medicinal Chemistry, $4^{\text {th }}$ Ed., Oxford University Press, Oxford, U.K., 2009, Chapter 13, p 230-232.

21. Meanwell, N.A.; J. Med. Chem., 2011, 54, 2529-2591.

22. For details of the Belbin questionnaire see http://www.belbin.com/rte.asp?id=396 (accessed $22^{\text {nd }}$ November 2012).

23. Folkes, A.J.; Ahmadi, K.; Alderton, W.K.; Alix, S.; Baker, S.J.; Box, G.; Chuckowree, I.S.; Clarke, P.A.; Depledge, P.; Eccles, S.A.; Friedman, L.S.; Hayes, A.; Hancox, T.C.; Kugendradas, A.; Lensun, L.; Moore, P.; Olivero, A.G.; Pang, J.; Patel, S.; Pergl-Wilson, G.H.; Raynaud, F.I.; Robson, A.; Saghir, N.; Salphati, L.; Sohal, S.; Ultsch, M.H.; Valenti, M.; Wallweber, H.J.A.; Wan, N.C.; Wiesmann, C.; Workman, P.; Zhyvoloup, A.; Zvelebil, M.J.; Shuttleworth, S.J.; J. Med. Chem. 2008, 51, 5522-5532.

24. a) Bayliss, T.; Chuckowree, I.; Folkes, A.; Oxenford, S.; Wan, N.C.; Castanedo, G.; Goldsmith, R.; Gunzner, J.; Heffron, T.; Mathieu, S.; Olivero, A.; Staben, S.; Sutherlin, D.P.; Zhu, B-Y., PCT Int. Appl., 2008, WO2008/70740. b) Zhu, W.; Zhai, X.; Fu, Q.; Guo, F.; Bai, M.; Wang, J.; Wang, H.; Gong, P.; Chem. Pharm. Bull., 2012, 60, 1037-1045.

25. Abdel-Magid, A.F.; Mehrman, S.J.; Org. Proc. Res. Dev., 2006, 10, 971-1031.

26. Slagt, V.F.; de Vries, A.H.M.; de Vries, J.G.; Kellogg, R.M.; Org. Proc. Res. Dev., 2010, 14 , 30-47.

27. Angehrn, P.; Buchmann, S.; Funk, C.; Goetschi, E.; Gmuender, H.; Hebeisen, P.; Kostrewa, D.; Link, H.; Luebbers, T.; Masciadri, R.; Nielsen, J.; Reindl, P.; Ricklin, F.; Schmitt-Hoffmann, A.; Theil, F-P.; J. Med. Chem., 2004, 47, 1487-1513. TBAF (tetrabutylammonium fluoride) deprotection also works: Greene, T. W.; Wuts, P. G. M. Protective Groups In Organic Synthesis, 3rd ed.; John Wiley \& Sons: New York, 1991.

28. Glaeske, K.W.; Naidu, B.N.; West, F.G.; Tetrahedron Asymm., 2003, 14, 917-920. Liu, J.; Numa, M.M.D.; Liu, H.; Huang, S-J.; Sears, P.; Shikhman, A.R.; Wong, C-H.; J. Org. Chem., 2004, 69, 6273-6283.

29. Sutherlin, D.P.; Bao, L.; Berry, M.; Castanedo, G.; Chuckowree, I.; Dotson, J.; Folkes, A.; Friedman, L.; Goldsmith, R.; Gunzner, J.; Heffron, T.; Lesnick, J.; Lewis, C.; Mathieu, S.; Murray, J.; Nonomiya, J.; Pang, J.; Pegg, N.; Prior, W.W.; Rouge, L.; Salphati, L.; Sampath, D.; Tian, Q.; Tsui, V.; Wan, N.C.; Wang, S.; Wei, B.; Wiesmann, C.; Wu, P.; Zhu, B-Y.; Olivero A.; J. Med. Chem. 2011, 54, 7579-7587.

30. The same potency enhancing co-operativity is observed where an indole replaces the indazole, see Safina, B.S.; Baker, S.; Baumgardner, M.; Blaney, P.M.; Chan, B.K.; Chen, YH.; Cartwright, M.W.; Castanedo, G.; Chabot, C.; Cheguillaume,A.J.; Goldsmith, P.; Goldstein, D.M.; Goyal, B.; Hancox, T.;Handa, R.K.; Iyer, P.S.; Kaur, J.; Kondru, R.; Kenny, J.R.; Krintel, S.L.; Li, J.; Lesnick, J.; Lucas, M.C.; Lewis, C.; Mukadam, S.; Murray, J.; Nadin, A.J.; Nonomiya, J.; Padilla, F.; Palmer, W.S.; Pang, J.; Pegg, N.; Price, S.; Reif, K.; Salphati, L.; Savy, P.A.; Seward, E.M.; Shuttleworth, S.; Sohal, S.; Sweeney, Z.K.; Tay, S.;

Tivitmahaisoon, P.; Waszkowycz, B.; Wei, B.; Yue, Q.; Zhang, C.; Sutherlin, D.P.; J. Med. Chem. 2012, 55, 5887-5900. 
Figure 5. Spotfire ${ }^{\mathrm{TM}}$ plot (molecular weight vs. clogP) for the array of amines. Each spot corresponds to a different target compound (amines A01 - A42), with the spots' shape and colour coded according to the number of hydrogen bond acceptors and donors, respectively. Students discuss target choice in relation to Lipinski's 'Rule of Five'.

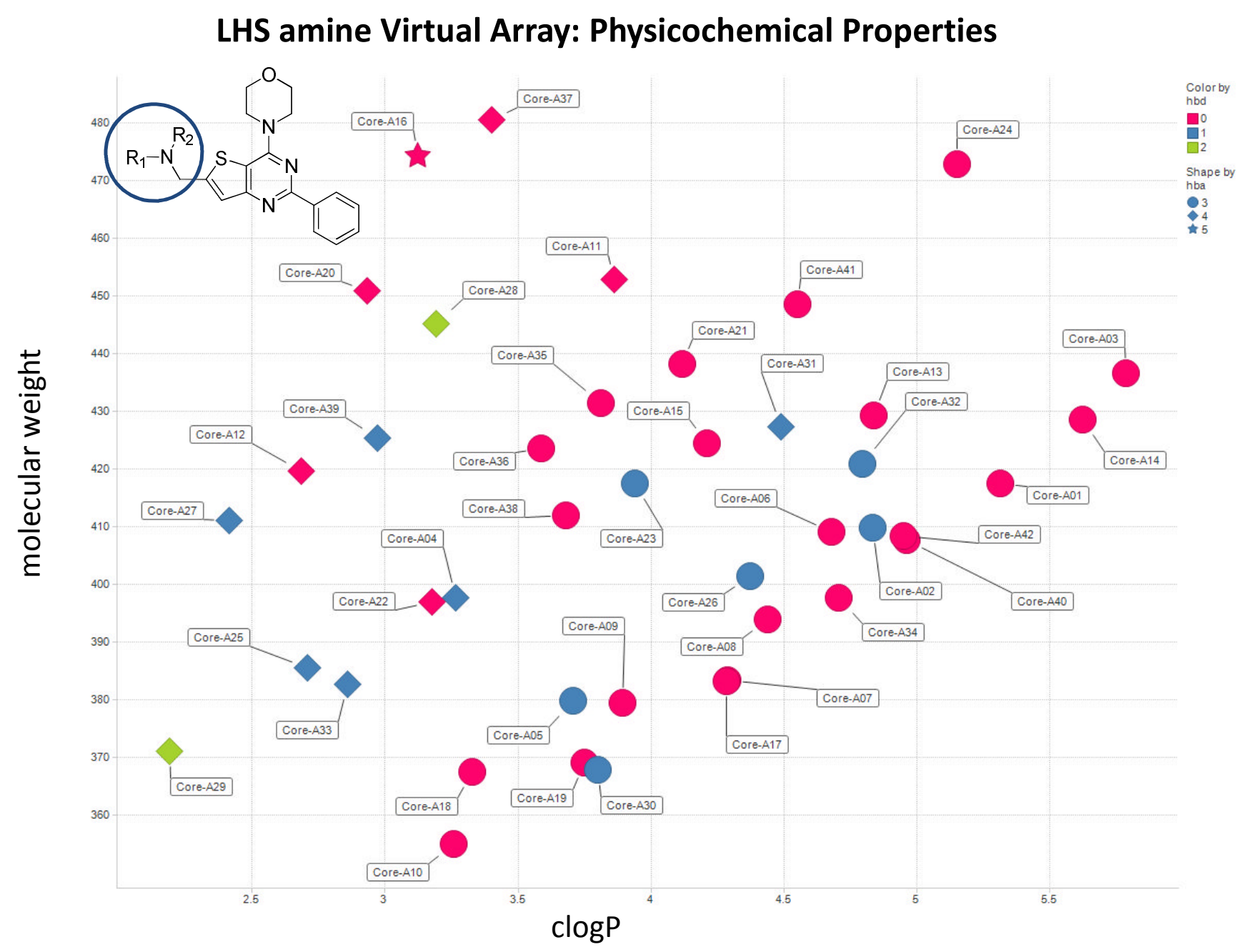


